\title{
THE
}

\section{The Distribution of the Mid-to-Lower Crustal Low-Velocity Zone Beneath the Northeastern Tibetan Plateau Revealed from Ambient Noise Tomography}

Hongyi Li

Yang Shen

University of Rhode Island, y.shen@icloud.com

Zhongxian Huang

Xinfu Li

Meng Gong

See next page for additional authors

Follow this and additional works at: https://digitalcommons.uri.edu/gsofacpubs

Terms of Use

All rights reserved under copyright.

\section{Citation/Publisher Attribution}

Hongyi Li; Yang Shen; Zhongxian Huang; Xinfu Li; Meng Gong; Danian Shi; Sandvol, E.; Aibing Li. (2014). "The distribution of the mid-to-lower crustal low-velocity zone beneath the northeastern Tibetan Plateau revealed from ambient noise tomography." Journal of Geophysical Research: Solid Earth. 119(3): 1954-70. Available at: http://dx.doi.org/10.1002/2013JB010374

This Article is brought to you for free and open access by the Graduate School of Oceanography at DigitalCommons@URI. It has been accepted for inclusion in Graduate School of Oceanography Faculty Publications by an authorized administrator of DigitalCommons@URI. For more information, please contact digitalcommons-group@uri.edu. 
Authors

Hongyi Li, Yang Shen, Zhongxian Huang, Xinfu Li, Meng Gong, Danian Shi, Eric Sandoval, and Aibeng Li

This article is available at DigitalCommons@URI: https://digitalcommons.uri.edu/gsofacpubs/59 


\section{Journal of Geophysical Research: Solid Earth}

\section{RESEARCH ARTICLE \\ 10.1002/2013JB010374 \\ Key Points: \\ - Group and phase velocities are inverted in NE Tibet \\ - The crustal LVZ thins out around the \\ The distribution of the mid-to-lower crustal low-velocity zone beneath the northeastern Tibetan Plateau revealed from ambient noise tomography} eastern Kunlun Mountains

- The NW Qilian Orogen with deeper Moho features a weak crustal LVZ

Supporting Information:

- Readme

- Figure S1a

- Figure S1b

- Figure S1C

- Figure S1d

- Figure S2

- Figure S3a

- Figure S3b

Correspondence to:

H. Li,

lih@cugb.edu.cn

Citation:

Li, H., Y. Shen, Z. Huang, X. Li, M. Gong, D. Shi, E. Sandvol, and A. Li (2014), The distribution of the mid-to-lower crustal low-velocity zone beneath the northeastern Tibetan Plateau revealed from ambient noise tomography, J. Geophys. Res. Solid Earth, 119, 1954-1970, doi:10.1002/2013JB010374.

Received 25 MAY 2013 Accepted 11 FEB 2014

Accepted article online 17 FEB 2014 Published online 18 MAR 2014 Tibetan Plateau.

\author{
Hongyi $\mathrm{Li}^{1,2}$, Yang Shen ${ }^{3}$, Zhongxian Huang ${ }^{4}$, Xinfu $\mathrm{Li}^{2}$, Meng Gong ${ }^{5}$, Danian Shi ${ }^{6}$, \\ Eric Sandvol ${ }^{7}$, and Aibing $\mathbf{L i}^{8}$ \\ ${ }^{1}$ Key Laboratory of Geo-detection, China University of Geosciences, Ministry of Education, Beijing, China, ${ }^{2}$ School of \\ Geophysics and Information Technology, China University of Geosciences, Beijing, China, ${ }^{3}$ Graduate School of \\ Oceanography, University of Rhode Island, Kingston, Rhode Island, USA, ${ }^{4}$ Institute of Crustal Dynamics, China Earthquake \\ Administration, Beijing, China, ${ }^{5}$ Hebei Province Seismological Bureau, Hebei, China, ${ }^{6}$ Institute of Mineral Resources, Chinese \\ Academy of Geological Sciences, Beijing, China, ${ }^{7}$ Department of Geological Sciences, University of Missouri, Columbia, \\ Missouri, USA, ${ }^{8}$ Department of Earth and Atmospheric Sciences, University of Houston, Houston, Texas, USA
}

Abstract We collected continuous seismic data recorded between 2007 and 2010 by 208 broadband stations from the Chinese Provincial Digital Seismic Networks, A Seismic Collaborative Experiment of Northern Tibet, and the Northeastern Tibet Seismic experiment. Cross correlations of vertical component records are computed to extract the Rayleigh wave empirical Green's functions. Group and phase velocities are then constructed from the empirical Green's functions in 8 to $50 \mathrm{~s}$ period. At periods $\leq 25 \mathrm{~s}$, more than $10 \%$ lower velocities are imaged beneath the Qaidam Basin, and high velocities are observed beneath the nonbasin regions. At periods $\geq 30 \mathrm{~s}$, up to $10 \%$ lower velocities are imaged in the Qiangtang and Songpan-Ganze Terranes. From these group and phase velocity maps, a three-dimensional (3-D) $V_{s v}$ model of the crust is derived. The model shows that the Qiangtang and Songpan-Ganze Terranes have a very thick crust with a prominent low-velocity zone (LVZ) in the middle crust. The LVZ thins out in the vicinity of the eastern Kunlun Mountains, providing a new constraint on the mode of deformation across the Tibetan Plateau. The northwestern Qilian Orogen, where receiver functions reveal a Moho deeper than the surrounding areas, also features a relatively weak midcrustal LVZ, which we interpret as an intracrustal response associated with the shortening between the North China Craton and the

\section{Introduction}

The Tibetan Plateau, with an average elevation of $4-5 \mathrm{~km}$ above sea level and a crustal thickness of about $60-80 \mathrm{~km}$, is the product of the northward convergence of the Indian Plate toward the Asian Plate since 50 Ma [Molnar and Tapponnier, 1975; Rowley, 1996; Yin and Harrison, 2000] and has been a prime site to understand the processes of continental collision and mountain building. Many models have been proposed to explain the formation of the Tibetan Plateau, and they can be generally sorted into: (1) uniform shortening and thickening of the Asian lithosphere [e.g., Dewey and Burke, 1973; England and Houseman, 1986], (2) underthrusting of the Indian continental lithosphere beneath the plateau [e.g., Barazangi and Ni, 1982; Owens and Zandt, 1997; Tilmann et al., 2003; Chen and Tseng, 2007], (3) the viscous flow model, in which the uplift of the plateau is associated with the flow in the mid-to-lower crust and/or upper mantle [e.g., England and Houseman, 1989; England and Molnar, 1997; Royden, 1996; Royden et al., 1997, 2008; Clark and Royden, 2000; Shen et al., 2001; Beaumont et al., 2001], and (4) the block extrusion/tectonic escaping of the Asian lithosphere along major strike-slip faults [Burchifel et al., 1989; Tapponnier et al., 1982, 2001].

There is no doubt that the northward subduction or underthrusting of India toward Asia has played a significant role in the rise and growth of the plateau. But to understand the growth of the plateau, we must also look at other boundaries that define the plateau, including the northeastern Tibetan Plateau, a tectonically active and complex area that features multiple terrains and is geographically defined by the Haiyuan fault system in the northeast, the eastern Kulun fault system in the southwest, and the Altyn Tagh 


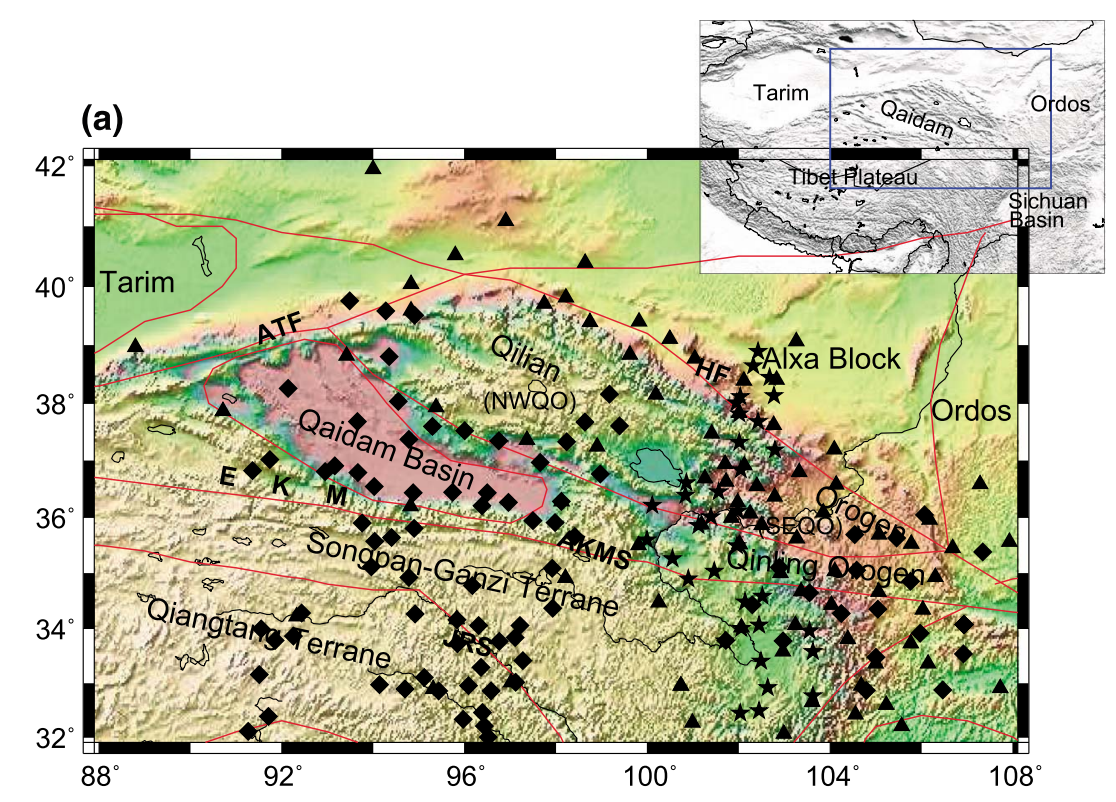

(b)

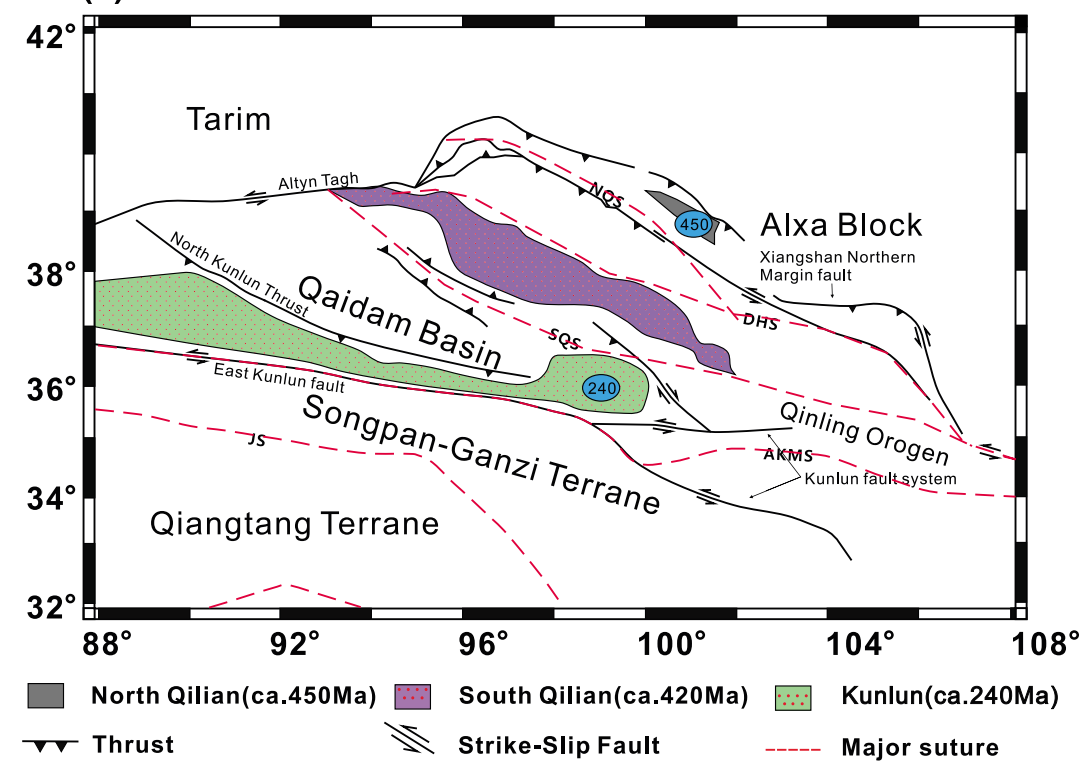

Figure 1. (a) A map view of station locations used in this study. Triangle represents regional stations deployed by China Earthquake Administration, stars are temporal stations deployed by NETS, diamonds are ASCENT stations, and red lines mark tectonic elements. The blue rectangle in the top right of the map marks the position of the study area. ATF: Altyn Tagh Fault, HF: Haiyuan Fault, EKM: eastern Kunlun Mountains, JRS: Jinsha-River Suture, AKMS: Ayimaqin-Kunlun-Mutztagh Suture, NWQO: northwestern Qilian Orogen, and SEQO: southeastern Qilian Orogen. (b) Simplified tectonic map of the northeastern Tibetan Plateau. NQS: North Qilian Suture, SQS: South Qilian Suture, and DHS: Danghe Nan Shan Suture.

fault system in the north as shown in Figure 1. At the northernmost boundary of the Tibetan Plateau, the Qilian Orogen consists of the complexly deformed early Paleozoic arcs developed at the southern margin of the North China Craton and undergoes active NE-SW shortening at a rate of $13 \mathrm{~mm} / \mathrm{yr}$ [Bilham et al., 1997; Yin and Harrison, 2000]. This area is about $800 \mathrm{~km}$ long in a WNW direction and over $300 \mathrm{~km}$ wide and has an average elevation of 3500 to $4000 \mathrm{~m}$. To the south, the Qaidam Basin is a Mesozoic intracontinental basin with a sedimentary sequence that varies in thickness from $\sim 5 \mathrm{~km}$ near the margins to $\sim 15 \mathrm{~km}$ in the center [Gu and Di, 1989]. 
Compared to the southern Tibetan Plateau, the northeastern Tibetan Plateau has relatively fewer seismic studies [e.g., Wittlinger et al., 1996; Zhu and Helmberger, 1998; Vergne et al., 2002; Rapine et al., 2003; Wittlinger et al., 2004; Zhao et al., 2006; Kumar et al., 2006; Shi et al., 2009; Li et al., 2012; Zhang et al., 2011a; Karplus et al., 2011; Yue et al., 2012], which are either highly localized along linear seismic profiles or have focused on the Moho discontinuity or the lithospheric mantle structure with the primary objectives of understanding the lithosphere interaction. Therefore, a detailed and comprehensive imaging of the crust across this margin is still critically needed to understand the crustal structure and to answer the question about the existence and extent of the mid-to-lower crustal flow beneath the northeast plateau margin.

In this paper, we apply the ambient noise tomography technique to image the crustal velocity structure in the northeastern plateau margin, which covers the Qilian Orogen, the western Qinling Orogen, the Qaidam Basin, and the eastern part of the Qiantang and Songpan-Ganze Terranes. We collected continuous seismic data recorded between 2007 and 2010 by 208 seismic stations from the Chinese Provincial Digital Seismic Networks, A Seismic Collaborative Experiment of Northern Tibet (ASCENT), and the Northeastern Tibet Seismic (NETS) experiment, obtaining a much denser data coverage of the northeastern Tibetan Plateau than in previous studies. In Figure 1, the vertical components of the seismic data are cross-correlated to estimate the Rayleigh wave Green's functions. Lateral variations of group and phase velocities are inverted from the Rayleigh wave dispersions, and the 3-D $V_{s v}$ model is constructed based on the Rayleigh wave tomography results. Our results show that the Qiangtang and Songpan-Ganze Terranes feature a prominent low-velocity zone (LVZ) in the middle crust, and the midcrustal LVZ thins out in the vicinity of the eastern Kunlun Mountains. A relatively weak LVZ in the middle crust is also observed beneath the northwestern Qilian Orogen, where a locally deeper Moho is observed. We suggest that the crustal thickening and the local LVZ beneath the northwestern Qilian Orogen reflect an intracrustal response associated with the shortening between the North China Craton and the Tibetan Plateau.

\section{Data and Dispersion Analysis}

In this study, we collected continuous vertical component seismic data recorded during the years 2007-2010 by 208 stations from the Chinese Provincial Digital Seismic Networks, and the temporary ASCENT and NETS experiments. The previous studies [Li et al., 2012; Yang et al., 2010, 2012] have given detailed descriptions of the seismic networks except for the NETS experiment; therefore, here we only introduce the NETS array deployed by China University of Geosciences in Beijing, Chinese Academy of Geological Sciences, University of Rhode Island, University of Houston, and University of Missouri. Figure 1 (black stars) shows the NETS array consisting of 35 broadband stations equipped with 26 Guralp CMG3ESP sensors and 9 Guralp CMG3TD sensors and was operated between June 2008 and July 2010 in the northeastern plateau margin.

The data processing procedure and data selection criteria for cross correlation are the same as described in our previous studies [Li et al., 2010, 2012; Yang et al., 2012] and therefore not elaborated here. After cross correlating, we cut the cross correlation function into positive and negative time lags and then add the two lags to generate an averaged cross correlation. The group and phase velocity dispersion curves between 8 and $50 \mathrm{~s}$ are extracted by time frequency analysis based on the multiple filter technique with phase-matched processing to isolate the fundamental mode surface waves [Dziewonski et al., 1969; Herrmann, 1973]. Since the dispersion curves here are taken from more than 12 month stacks in this study, we computed the standard deviation for a station pair if more than four 3 month stacks have a signal-to-noise ratio $>8$, and we have discarded the measurements with standard deviations that are larger than $120 \mathrm{~m} / \mathrm{s}$.

In Figure 2, we show synthetic examples to illustrate how a LVZ in the crust affects dispersion curves. Figure $2 \mathrm{c}$ shows the group velocity dispersion curves generated from the models with a LVZ showing a pronounced velocity minimum around $26 \mathrm{~s}$ with a $50 \mathrm{~km}$ Moho and around $36 \mathrm{~s}$ with a $70 \mathrm{~km}$ Moho. So a vertically localized minimum of shear wave velocity in the crust can produce a pronounced change in the group velocity dispersion curve. However, since the group velocity dispersion curve usually does not increase monotonically and usually has a velocity minimum associated with the airy phase at around $20 \mathrm{~s}$, it is hard to distinguish the effects of the LVZ in the crust only from the gradient of the dispersion curve. Figure $2 d$ (dotted lines) shows that when a midcrustal LVZ is present in the models with either a shallow or deep Moho, the phase velocity dispersion curves are flattened or concaved, different from those without a midcrustal LVZ. 

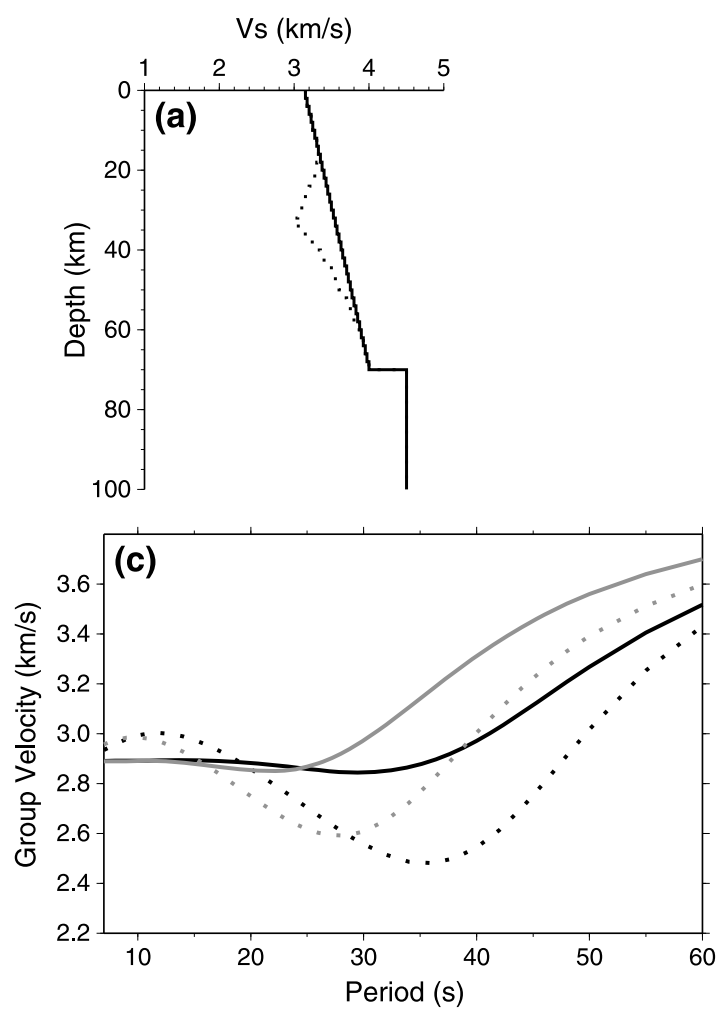
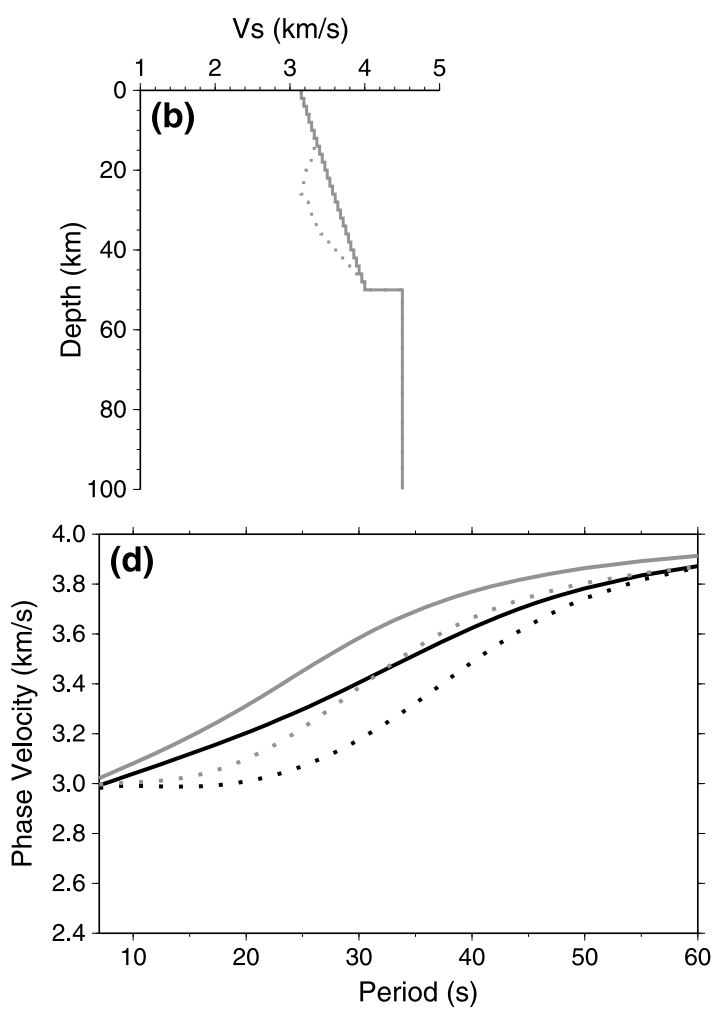

Figure 2. (a) Two synthetic shear wave velocity models with a thick Moho depth of $70 \mathrm{~km}$, the black dot line denotes the model with a low-velocity zone in the crust and the black solid line without a low velocity zone in the crust. (b) Two synthetic shear wave velocity models with a Moho depth of $50 \mathrm{~km}$, the gray dot line denotes the model with a low-velocity zone in the crust, and the gray solid line without a low-velocity zone in the crust. (c) Group velocity and (d) phase velocity dispersion curves calculated from the four velocity models shown on Figures $2 a$ and $2 b$, color coded similarly.

Figure 3 displays the measured group and phase velocity dispersion curves for station pairs located in different geological regions. In Figures 3b-3f, we note that all the dispersion curves measured from the station pairs located in the Songpan-Ganze Terrane and the northwestern Qilian Orogen show a decrease in group velocity with periods between 16 and $36 \mathrm{~s}$ and a flattened or concave phase velocity between 10-20 s. In contrast, in Figures 3g-3i, the dispersion curves of the station pairs located in the Qaidam Basin and the southeastern Qilian Orogen generally exhibit an increase in group velocity with periods greater than $24 \mathrm{~s}$ and convex phase velocity. It is also apparent that the station pairs located in the Qaidam Basin have much lower group and phase velocities at short periods than the one located in the southeastern Qilian Orogen.

\section{Group and Phase Velocity Tomography}

Figure 4a gives the number of Rayleigh wave group and phase velocity dispersion measurements at periods between 8 and $50 \mathrm{~s}$. In total, in Figures 4b and 4c, more than 5000 station pairs were used to invert for the Rayleigh wave group and phase velocity distributions. To understand the resolution, the study area is discretized into a $0.4^{\circ} \times 0.4^{\circ}$ grid, and each grid has a constant velocity of $5 \%$ above or below an average velocity of $2.9 \mathrm{~km} / \mathrm{s}$ to form a checkerboard pattern. Velocities between grid nodes are computed with bilinear interpolation. The Occam's inversion technique [Constable et al., 1987; deGroot-Hedlin and Constable, 1990] is adopted to invert for the velocity distributions. The final obtained model is the result of a compromise between achieving a good data variance reduction and maintaining a reasonable smoothness for the velocity model. A recent application with detailed discussion of this method can be found in the works of $L i$ et al. [2009]. As seen in Figures 4d and 4e, the lateral resolution of group and phase velocities at $24 \mathrm{~s}$ is about $40-50 \mathrm{~km}$ in most parts of the study area except in the margins where the paths are few or generally in one direction without crossing each other. At 

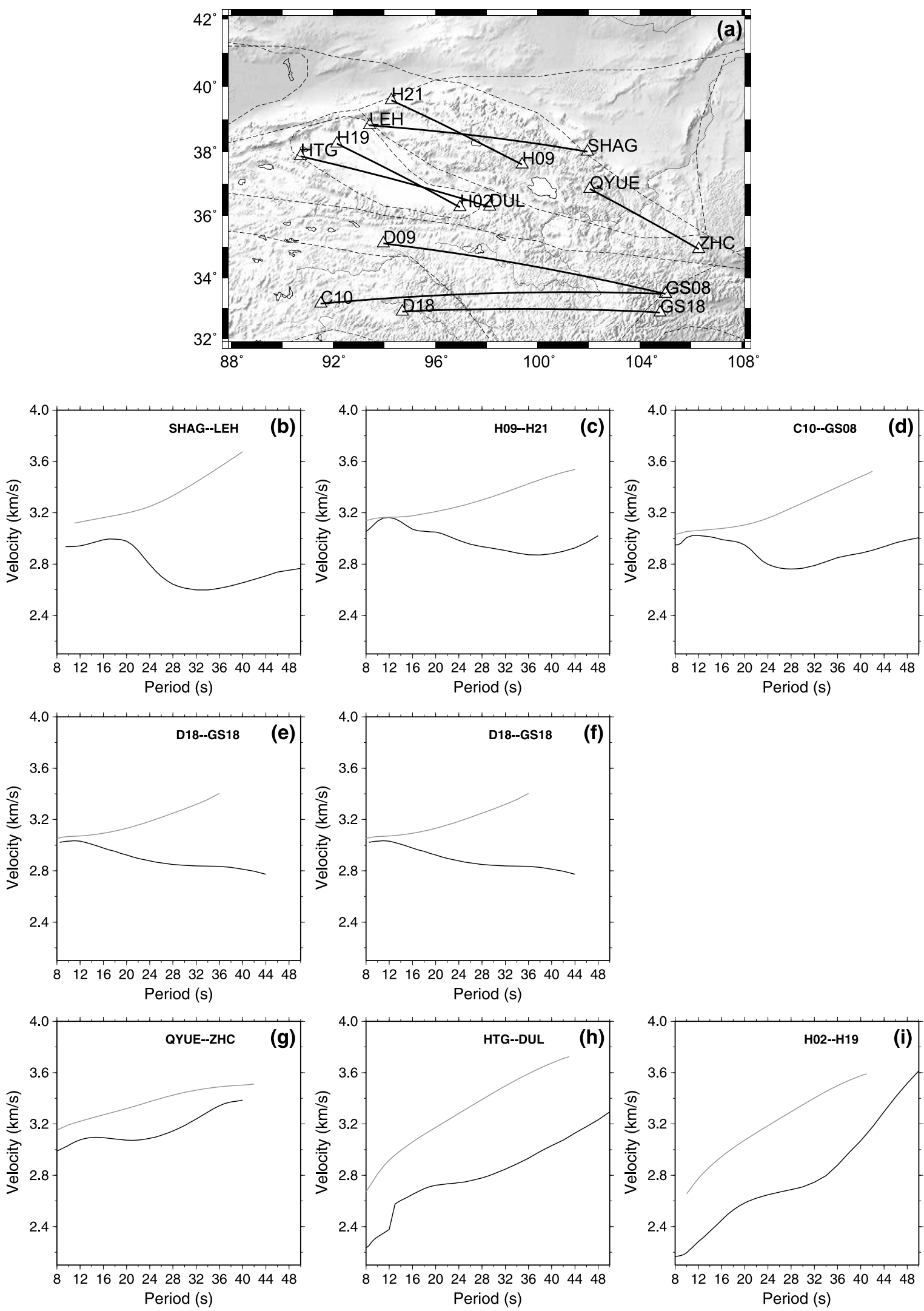

Figure 3. (b-i) Examples of group and phase velocity curves measured from (a) station pairs located in different tectonic units, black line represents group velocity dispersion curve and gray line denotes phase velocity dispersion curve. 

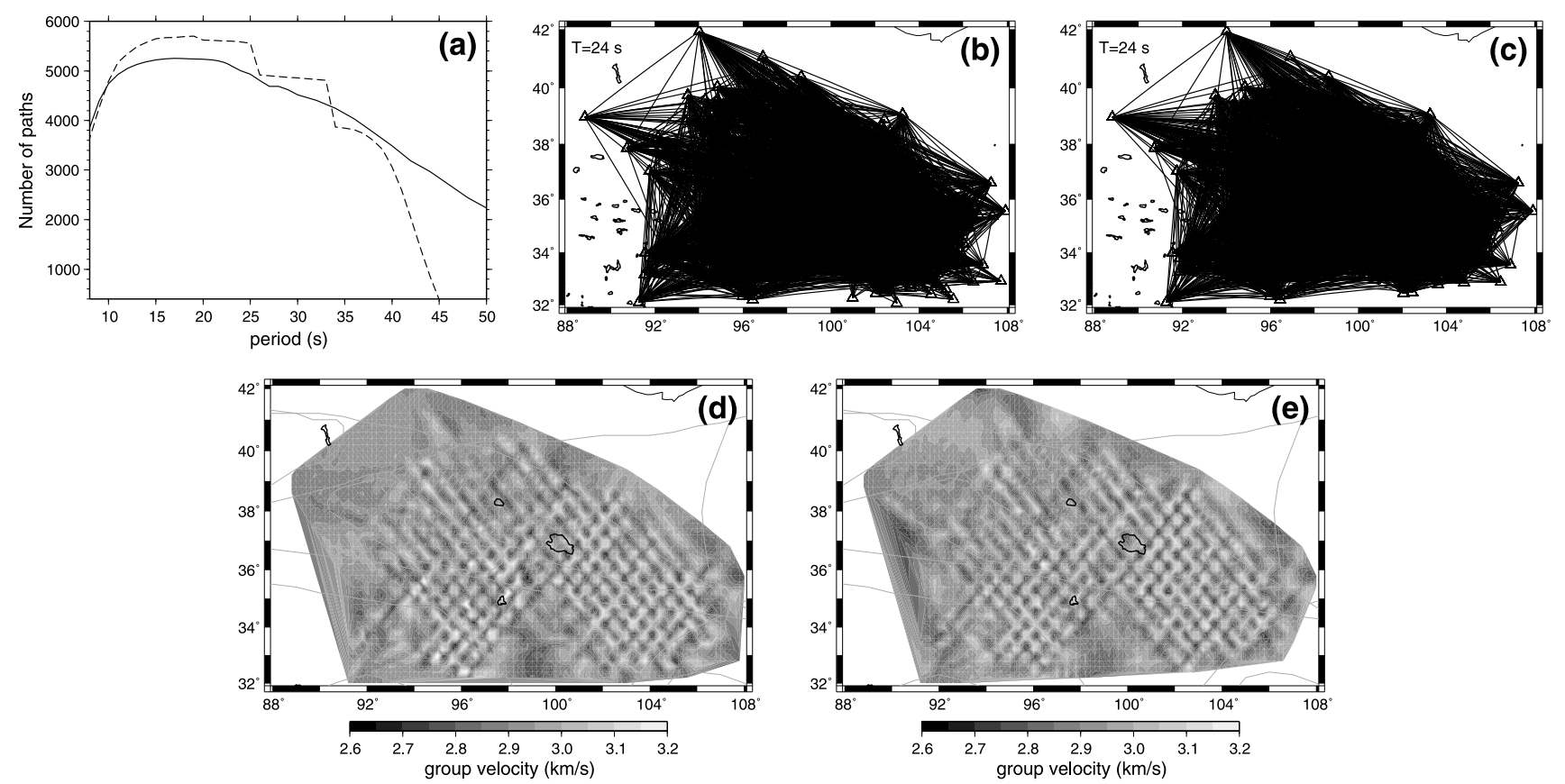

Figure 4. (a) Plot of group velocity (solid line) and phase velocity (dashed line) dispersion measurements for different periods used in this study. Path coverage of (b) group velocity and (c) phase velocity measurements at $24 \mathrm{~s}$. (d and e) The recovered checkerboard for group and phase velocities at $T=24$ swith a grid size of $0.4^{\circ} \times 0.4^{\circ}$, respectively.

periods less than $40 \mathrm{~s}$, the path coverage is generally good, and lateral resolution remains about 40-50 km (Figure S1 in the supporting information). At periods longer than $40 \mathrm{~s}$, the path coverage becomes worse, and the lateral resolution decreases to about $80-100 \mathrm{~km}$. In the above estimates, the effects of finite frequency wave propagation are not accounted for, so the true scales of resolvable structures are likely larger. Nevertheless, these estimates provide a way to compare with earlier studies using similar methods.

The group and phase velocities of the Rayleigh wave at periods of 10, 24, 34, and $40 \mathrm{~s}$ are shown in Figure 5. At the short periods $(<20 \mathrm{~s})$, surface wave velocities are mainly sensitive to the upper crust velocity structure. Since sediments feature much slower seismic velocities than crystalline rocks, sedimentary basins usually stand out as low-velocity anomalies at short periods. The $10 \mathrm{~s}$ period group and phase velocity maps shown in Figure 5 clearly exhibit low velocities beneath the Qaidam Basin.

At $24 \mathrm{~s}$ period, Figure $5 \mathrm{~b}$ shows that low group velocities still persist beneath the Qaidam Basin due to the influence of sedimentary layers. Velocities beneath the Qiangtang and Songpan-Ganze Terranes appear lower overall than the surrounding regions at this period and at the intermediate and long periods (24-50 s). In Figure 5f, the Qiangtang and Songpan-Ganze Terranes also have the lowest phase velocities at this period, although the pattern of the phase velocity is somewhat different from the group velocity distribution. The difference between the group and phase velocity maps may reflect different sensitivities of group and phase velocities to velocity changes with depth as shown in Figure $\mathrm{S} 2$ in the supporting information.

At periods longer than 30 s, Rayleigh wave velocities are influenced by the Moho depth and shear velocities in the lower crust and the uppermost mantle. As seen in Figure 5 , in Figure $6 \mathrm{~g}$ the group and phase velocity maps at periods from 30 to $40 \mathrm{~s}$ are inversely correlated with the Moho depth [Zhang et al., 2011b; Yue et al., 2012], with high velocities in areas with shallow Moho depth and low velocities in areas with deep Moho depth. Furthermore, it is evident that at periods longer than $30 \mathrm{~s}$, the northwestern Qilian Orogen generally exhibits lower velocities than the southeastern Qilian Orogen, which are also mostly due to the differences in the Moho depth between the northwestern and southeastern Qilian Orogens. 

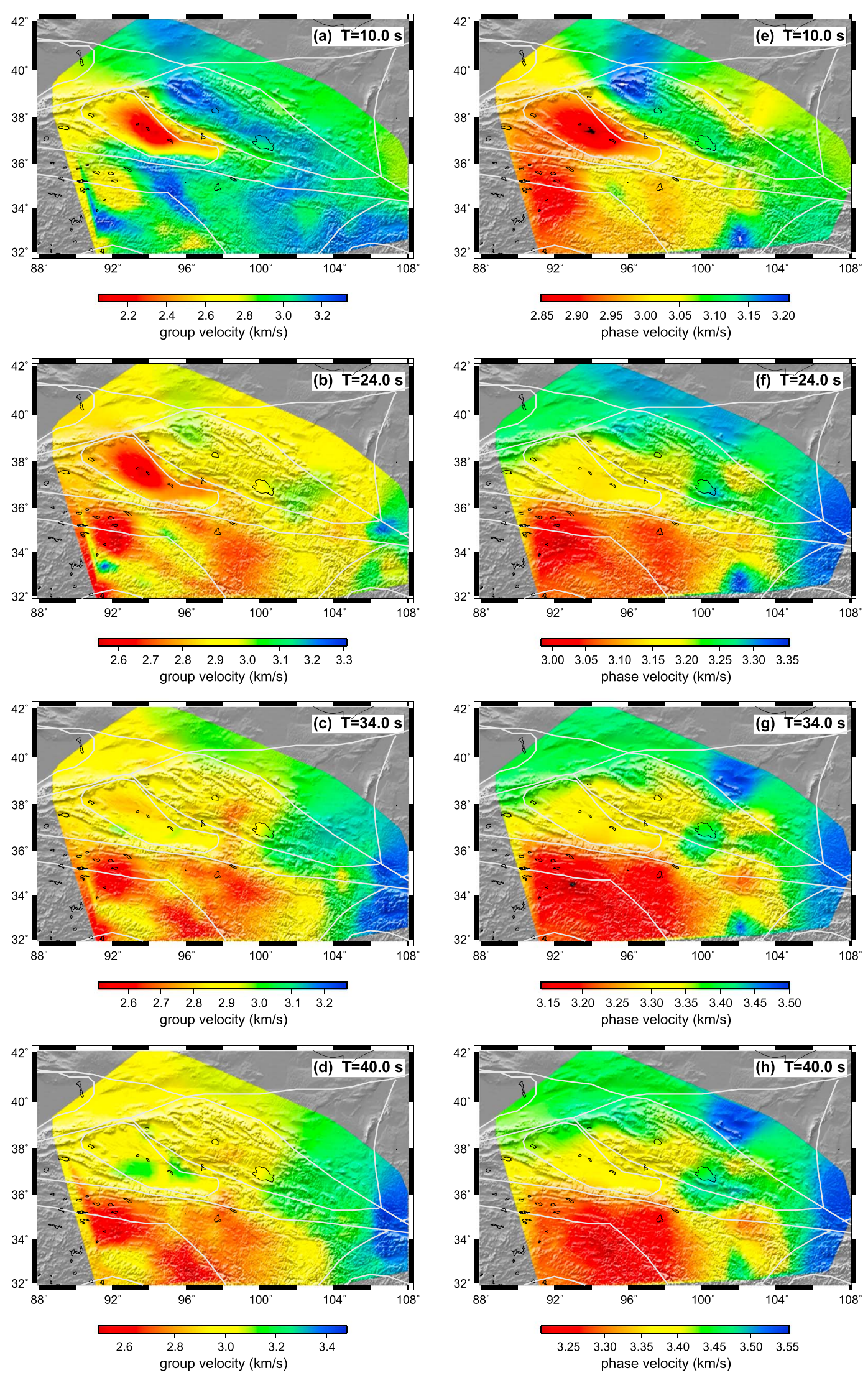

Figure 5. Estimated Rayleigh wave (a-d) group velocity and (e-h) phase velocity distributions at periods of $10 \mathrm{~s}, 24 \mathrm{~s}, 34 \mathrm{~s}$, and $40 \mathrm{~s}$, respectively. 

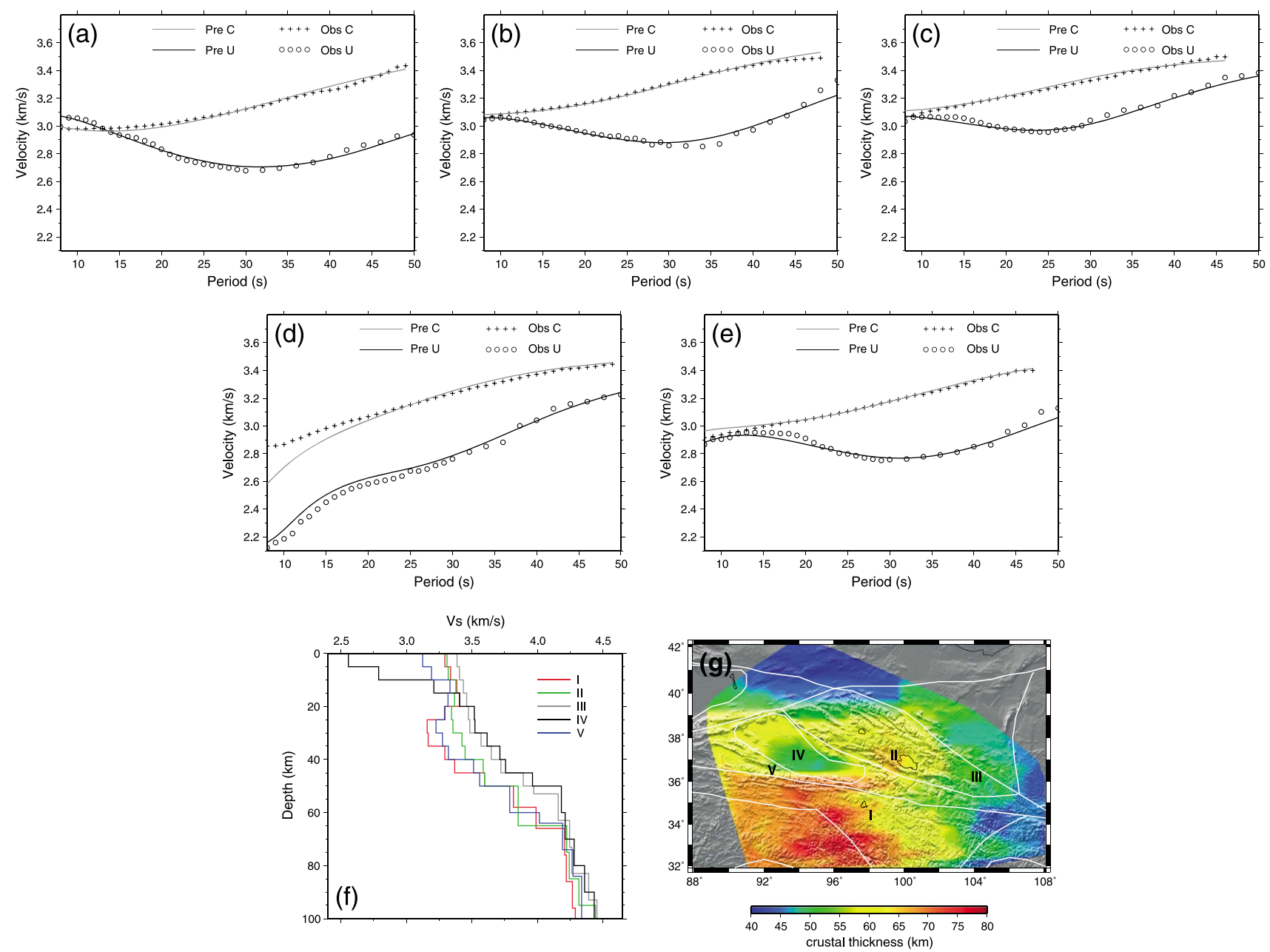

Figure 6. (a-e) Rayleigh wave group velocity (circles) and phase velocity (crosses) measurements are compared with (g) predicted group velocity (black lines) and phase velocity (gray lines) from the five grid nodes labeled by Roman letters. (f) $V_{s v}$ velocity profiles for the five grids. (g) Map of crustal thickness used in this study.

\section{Three-Dimensional $V_{s v}$ Velocity Structure}

From the above group and phase velocity distributions, we first extract the pure path dispersion curves at each node on a $0.4^{\circ} \times 0.4^{\circ}$ grid and use the pure path dispersion curves to invert for a set of 1-D $V_{s v}$ velocity structure at each grid node using a program developed by Herrmann and Ammon [2004] with linear steps. Then the 1-D profiles are assembled together to construct the final 3-D $V_{s v}$ velocity model. Since surface wave velocities are most sensitive to the shear wave velocity, we invert only for shear wave velocities. During the inversion, we assumed constant velocity and density in each layer. The $V p / V s$ ratio of each layer is fixed to 1.75 , and the $P$ wave velocity is updated accordingly as the $S$ wave velocity changes, then density is calculated using the Nafe-Drake relation. Layered starting models from the surface down to $120 \mathrm{~km}$ overlying on a half space are adopted in our inversion, and the layer thickness is $5 \mathrm{~km}$ for the top $50 \mathrm{~km}$ and $10 \mathrm{~km}$ for the next $70 \mathrm{~km}$ as shown in Figure $\mathrm{S3}$ (dashed line) in the supporting information. Because of surface waves' limited ability in resolving the velocity discontinuity and the trade-off between the shear wave velocity and the crustal thickness, the initial shear wave velocity models and Moho depths are referred to previous tomography and receiver function results [Huang et al., 2003; Pan and Niu, 2011; Zhang et al., 2011b; Yue et al., 2012]. The Moho depths are shown in Figure $6 \mathrm{~g}$.

In Figures 6a-6e, we give the observed and predicted (from the shear wave velocity structure in Figure 6f) pure path group and phase velocity dispersion curves for five grids located in the Songpan-Ganze Terrane, 


\section{AGU Journal of Geophysical Research: Solid Earth}
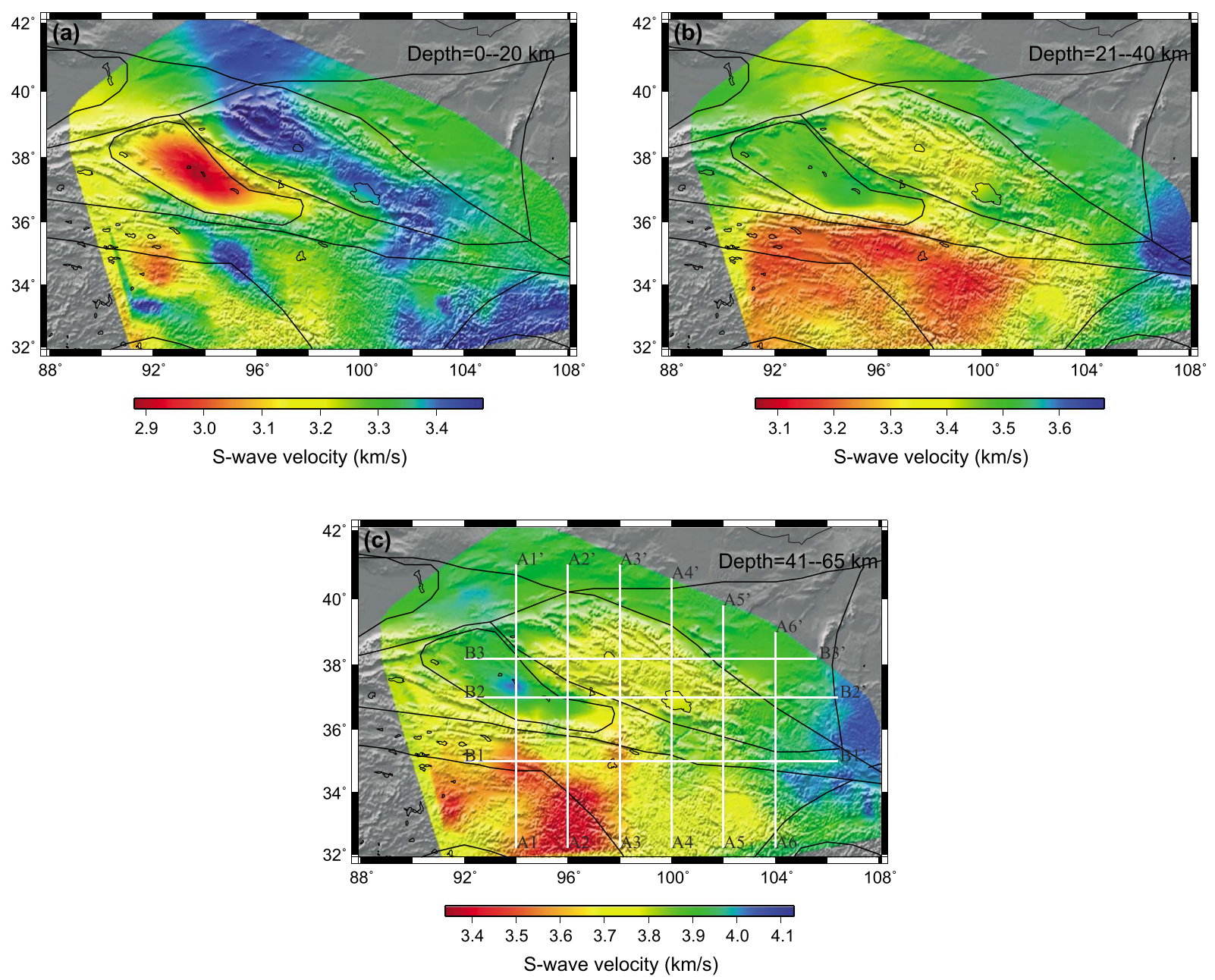

Figure 7. Averaged $V_{s v}$ velocities from (a) 0 to $20 \mathrm{~km}$ depth, (b) 21 to $40 \mathrm{~km}$ depth, and (c) 41 to $65 \mathrm{~km}$ depth. Lines in Figure $7 \mathrm{c}$ delineate the locations of the cross sections shown in Figure 8.

northwestern Qilian Orogen, southeastern Qilian Orogen, Qaidam Basin,and eastern Kunlun Mountains, respectively. The measurements and predictions are generally consistent with each other.

In Figure $6 f$, we exhibit the $V_{s v}$ velocity structure at the five grids. The Qaidam Basin has very low velocities at shallow depths, consistent with a thick sediment layer at the top. The Songpan-Ganze and Qiangtang Terranes have a very obvious low-velocity layer at depths of $\sim 20 \mathrm{~km}$ to $40 \mathrm{~km}$. The eastern Kunlun Mountains have similar features as those of the Songpan-Ganze and Qiangtang Terranes. The northwestern Qilian Orogen displays a weak low-velocity layer at depths of $\sim 20 \mathrm{~km}$ to $40 \mathrm{~km}$; however, there is no low-velocity layer beneath the southeastern Qilian Orogen.

In Figure $7 \mathrm{a}$, we plot the $V_{s v}$ velocities averaged from the surface to $20 \mathrm{~km}$ depth. The velocity distribution correlates well with surface geology. The low velocities are confined predominantly to the Qaidam Basin due to its thick sedimentary cover, and faster velocities appear in the nonbasin regions. Figure $7 \mathrm{~b}$ presents the $V_{s v}$ velocities averaged from $21 \mathrm{~km}$ to $40 \mathrm{~km}$, and this depth range represents approximately the middle crust in the Tibetan Plateau. A prominent feature in this image is the pronounced low velocities of the Songpan-Ganze and Qiangtang Terranes. The Qaidam Basin starts to show up with relatively high velocities, reflecting the basement without a LVZ. It is notable that the southeastern and northwestern Qilian Orogens show different velocity distribution patterns, and the northwestern Qilian Orogen has lower velocities than the southeastern Qilian. The southeastern and northwestern Qilian have distinctly different geological characters: Paleozoic magmatic rocks are widely distributed in the northwestern Qilian but not in the 

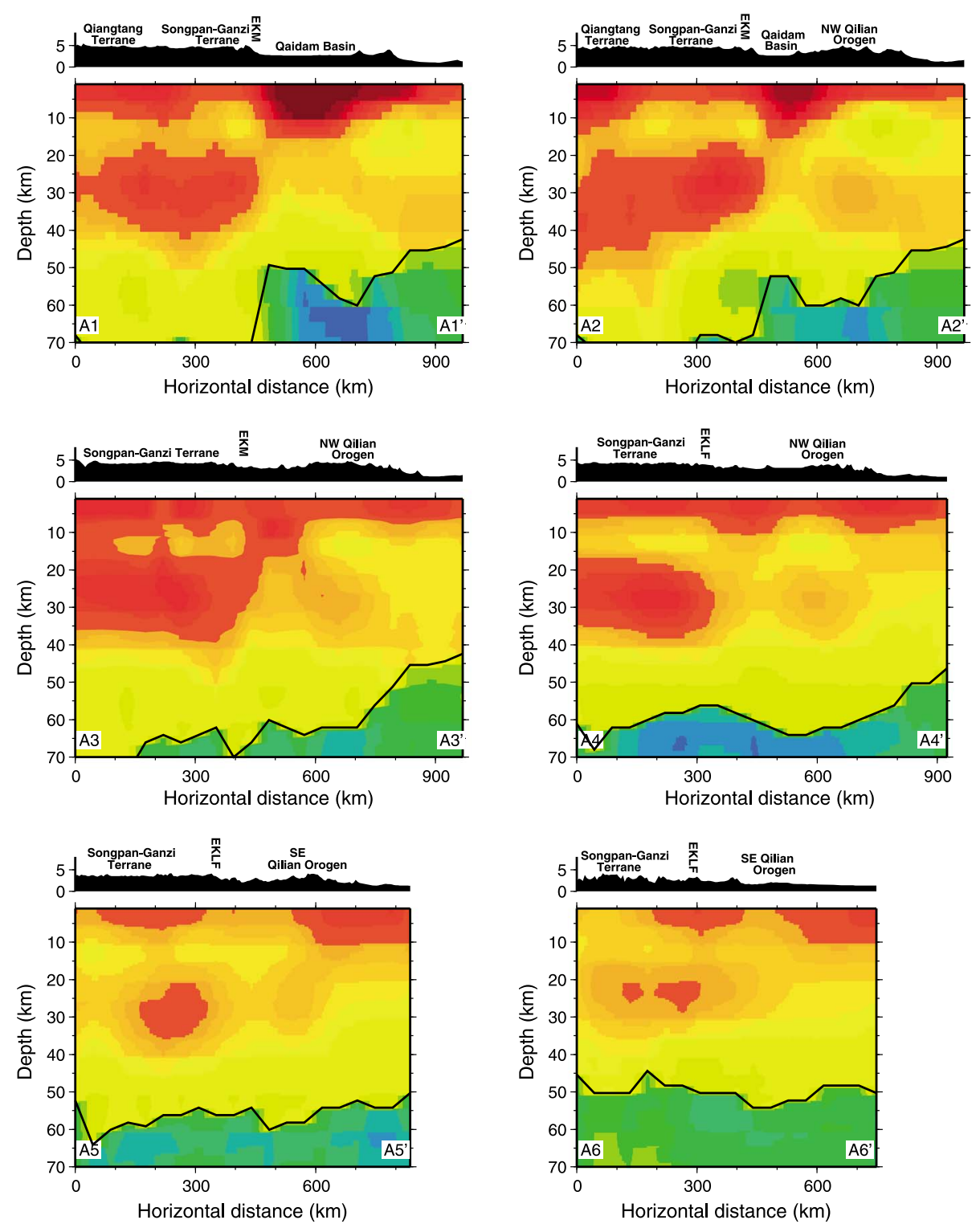

Figure 8. Vertical cross sections of $V_{s v}$ velocity along the nine profiles identified in Figure 7c. Black lines represent the crustal thickness used in this study as shown in the Figure $6 \mathrm{~g}$. Topography is plotted above each profile (black area).

southeastern Qilian, and the northwestern Qilian Orogen features a relative high heat flow value of $66 \mathrm{mWm}^{-2}$ [Wang, 2001]. These differences are indicative of a hotter and weaker lithosphere beneath the northwestern Qilian Orogen. Recent phase velocity tomography across the whole plateau [Yang et al., 2012] also observed low velocities at depths of 15 and $30 \mathrm{~km}$ beneath the northwestern Qilian Orogen, although their lateral resolution is about $100-200 \mathrm{~km}$. Surface wave tomography based on ambient noise and earthquake data [Bao et al., 2013] showed a $20 \mathrm{~km}$ thick, isolated midcrustal LVZ beneath the northwestern Qilian Orogen. Receiver function results from the works of Yue et al. [2012] revealed that there is an $\sim 10 \mathrm{~km}$ difference in the Moho depth between the northwestern and southeastern Qilian. Beneath the northwestern Qilian Orogen, the average crust thickness is about $60-65 \mathrm{~km}$. In contrast, the southeastern Qilian Orogen has an average Moho depth around $50 \mathrm{~km}$. Therefore, both the midcrustal LVZ and the deep Moho can contribute to the differences in the dispersion curves between the two areas.

The $V_{s v}$ velocities averaged from 41 to $65 \mathrm{~km}$ depth are given in Figure 7c. The velocity features in this depth range are generally the same as in Figure $7 \mathrm{~b}$. Due to the relatively thin crust beneath the Qaidam Basin, 

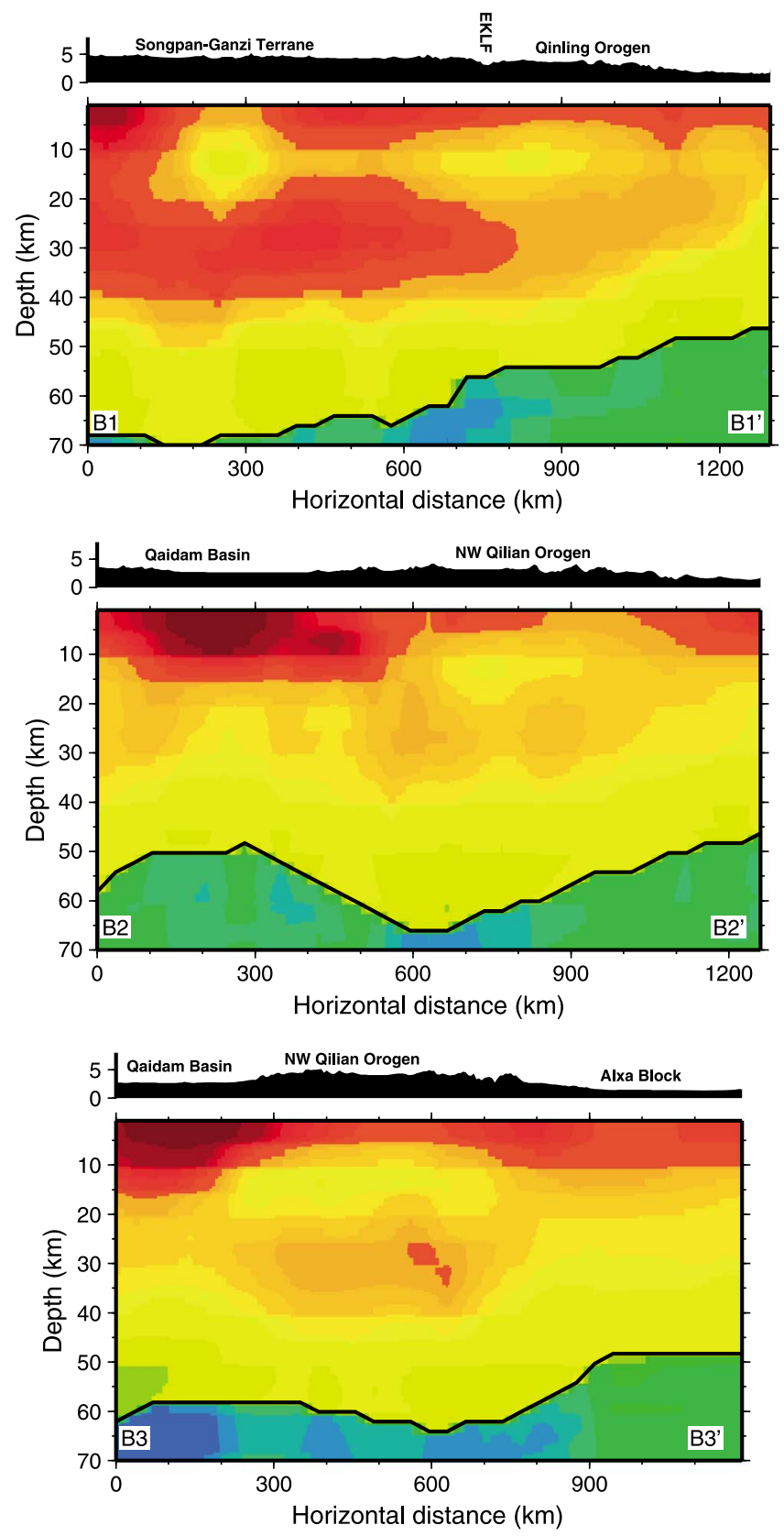

$\begin{array}{lllllllll}2.6 & 2.8 & 3.0 & 3.2 & 3.4 & 3.6 & 3.8 & 4.0 & 4.2\end{array}$

Figure 8. (continued)

southeastern Qilian Orogen, and western Qinling Orogen, the velocities reflect the mean velocities of the lower crustal and the uppermost mantle. In the northwestern Qilian Orogen, Songpan-Ganze, and Qiangtang Terranes, however, the Moho depth reaches about $65-80 \mathrm{~km}$; therefore, this depth is still a lower crust depth, and apparent low velocities reside in these regions.

Figure 8 presents nine $V_{s v}$ velocity profiles from the surface down to $70 \mathrm{~km}$ depth along six longitudes and three latitudes. In the $\mathrm{A} 1-\mathrm{A} 1^{\prime}$ profile along $94^{\circ} \mathrm{E}$, the Qaidam Basin shows a very thick sedimentary layer. A clear midcrustal LVZ ( 20-35 km) is present only beneath the Qiangtang and Songpan-Ganze Terranes and is not observed beneath the Qaidam Basin. 
The profile A2-A2' along $96^{\circ} \mathrm{E}$, which crosses the southeastern Qiangtang Terrane, the eastern Songpan-Ganze Terrane, the southern Qaidam Basin, and the northwestern Qilian Orogen, also shows a thick sedimentary cover beneath the Qaidam Basin. A prominent midcrustal LVZ is revealed beneath the Qiangtang and SongpanGanze Terranes and terminates beneath the Qaidam Basin. The extent and amplitude of the LVZ beneath the Qiangtang Terrane appear much stronger than beneath the Songpan-Ganze Terrane. However, since it is close to the margin of our study area, the resolution beneath the southeastern Qiangtang Terrane is not very good and it could be a consequence of smearing, and more data in a wider study region are required to verify this. We note that the northwestern Qilian Orogen also presents a relatively weak LVZ ( 20-40 km) compared with the Qiangtang and Songpan-Ganze Terranes. The distribution of this feature correlates roughly to the region with a relatively thick crust from recent receiver function studies [Yue et al., 2012].

The profiles $\mathrm{A} 3-\mathrm{A} 3^{\prime}$ along $98^{\circ} \mathrm{E}$ and $\mathrm{A} 4-\mathrm{A} 4^{\prime}$ along $100^{\circ} \mathrm{E}$, through the Songpan-Ganze Terrane, the southern edge of the Qaidam Basin, and the northwestern Qilian Orogen, are similar to the profile A2-A2'. A LVZ exists in the middle crust beneath the Songpan-Ganze Terrane but apparently disappears around the eastern Kunlun Mountains, and a weak LVZ also resides beneath the northwestern Qilian Orogen. In the profiles $\mathrm{A} 5-\mathrm{A} 5^{\prime}$ along $102^{\circ} \mathrm{E}$ and $\mathrm{A} 6-\mathrm{A} 6^{\prime}$ along $104^{\circ} \mathrm{E}$, starting from the eastern Songpan-Ganze Terrane and ending in the southeastern Qilian orogeny, the LVZ exists in the Songpan-Ganze Terrane but obviously becomes weak near the eastern Kunlun Fault. No crustal LVZ is observed in the southeastern Qilian Orogen.

In profiles $\mathrm{B} 1-\mathrm{B} 1^{\prime}$ along $35^{\circ} \mathrm{N}$, through the Songpan-Ganze Terrane to the western Qinling Orogen, the most striking feature is an evident LVZ in the middle crust beneath the Songpan-Ganze Terrane. In profiles B2-B2' along $37^{\circ} \mathrm{N}$ and $\mathrm{B} 3-\mathrm{B} 3^{\prime}$ along $38.2^{\circ} \mathrm{N}$, starting from the Qaidam Basin, across the northwestern Qilian Orogen and reaching the Alxa Block, a very weak low-velocity layer in the middle crust exists beneath the northwestern Qilian Orogen.

\section{Discussion}

To assess whether the midcrustal LVZs are widespread in the northeastern Tibetan Plateau in a more quantitative way and whether the Kunlun Fault can be considered as a significant rheological boundary between the weak, the warm Tibetan crust, and the rigid Qaidam Block, we present two different measurements of a LVZ, following Yang et al. [2012]:

$$
\begin{gathered}
L V Z_{1}=\frac{V(30 \mathrm{~km})-V_{\text {ref }}}{V_{\text {ref }}} \\
L V Z_{2}=\frac{V(30 \mathrm{~km})-V_{\max }(0-20 \mathrm{~km})}{V_{\text {ref }}}
\end{gathered}
$$

As in the works of Yang et al. [2012], we set the reference shear wave velocity, $V_{\text {ref }}=3.45 \mathrm{~km} / \mathrm{s}$, since a dry crustal metamorphic rock at $30 \mathrm{~km}$ depth near the melting point has a shear wave velocity of about $3.45 \mathrm{~km} / \mathrm{s}$ [Litvinovsky et al., 2000]. This velocity is also the average velocity across the northeastern plateau between 20 and $40 \mathrm{~km}$ depth as shown in Figure 7b. Therefore, a negative value from the first equation indicates a likely presence of melt/fluid at $30 \mathrm{~km}$ in the crust or/and compositional differences. In equation $2, V_{\max }(0-20 \mathrm{~km})$ denotes the highest shear wave velocity between the surface and the $20 \mathrm{~km}$ depth, and $V_{\text {ref }}$ has the same definition as in equation 1. Equation 2 thus identifies areas with a vertically localized shear wave velocity minimum.

Figure 9 shows that the two definitions of the LVZ depict a generally similar distribution of the LVZ beneath the northeastern Tibetan Plateau. Pronounced LVZs primarily exist beneath the Songpan-Ganze and Qiangtang Terranes. We note that the northwestern Qilian Orogen is also delineated by negative anomalies (LVZ). Furthermore, the negative anomaly can be clearly seen beneath the east Kunlun Mountains, west of $98-100^{\circ} \mathrm{E}$, but becomes weak or disappears east of $98-100^{\circ} \mathrm{E}$, where the Kunlun Fault system bifurcates into two branches.

Results from analysis of phase velocity in Tibet [Yang et al., 2012] also showed that the Songpan-Ganze and Qiangtang Terranes and the northwestern Qilian Orogen exhibit lower velocities in the mid-to-lower crust at 

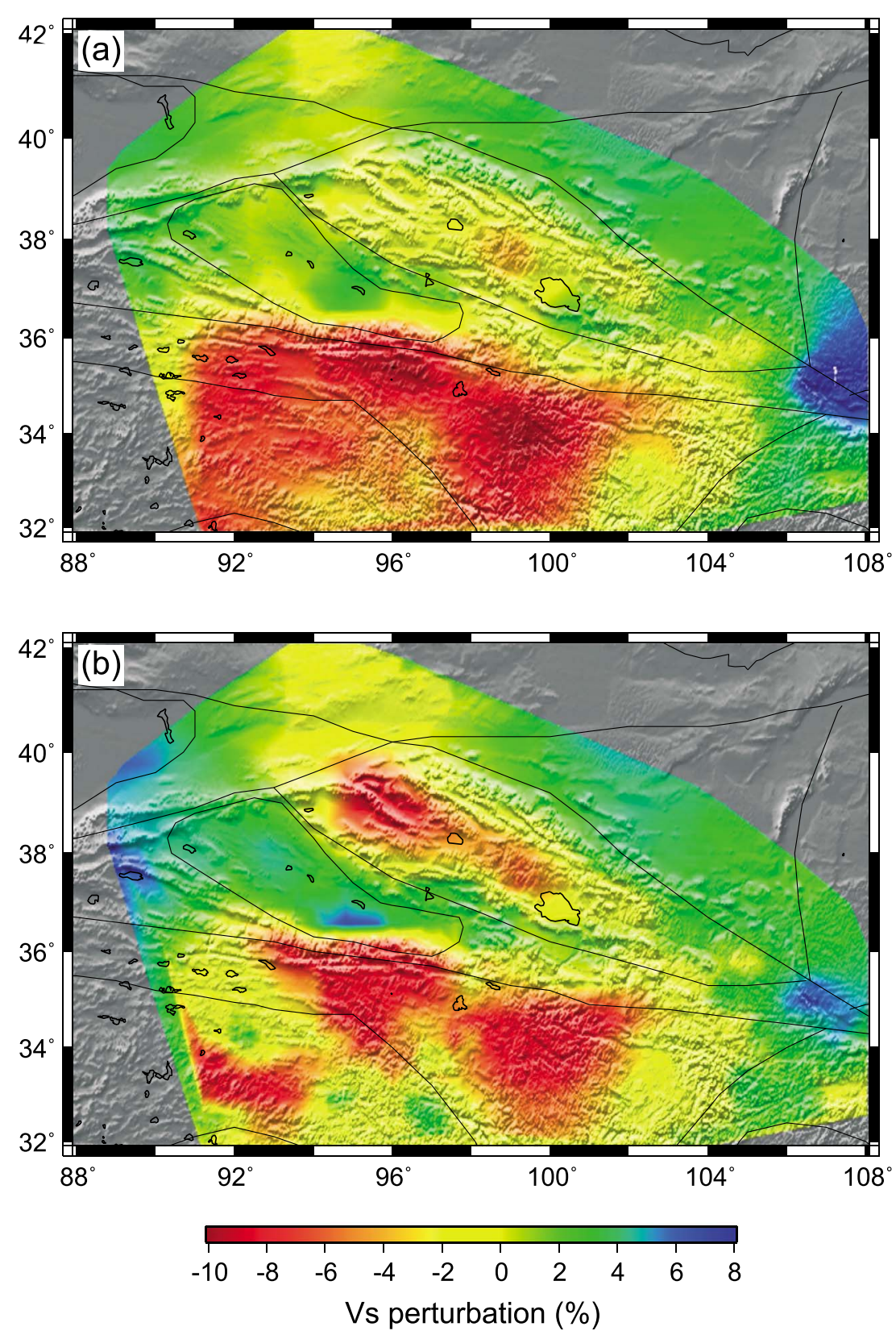

Figure 9. (a) Map of the amplitude of the crustal low-velocity zone based on the definition given by equation 1 [Yang et al., 2012]. (b) Same as Figure 9a, but with the definition of the amplitude of the crustal low-velocity zone give by equation 2 , which specifically measures a depth localized velocity minimum.

a lateral resolution about $100-200 \mathrm{~km}$. From the joint inversion of ambient noise and earthquake data, Bao et al. [2013] also revealed an isolated midcrustal LVZ at a depth range of 20-40 km beneath the northwestern Qilian Orogen, the area with a thickened crust and the highest topography compared with its surrounding regions, but the horizontal resolution of their tomography results is $\sim 2^{\circ}$ in the northeastern plateau. They suggested that the northeastern plateau is young and growing northward, so the isolated LVZ beneath the northwestern Qilian Orogen may represent an early stage of the LVZs that have developed in other parts of the plateau; however, their results have poor resolution beneath the Qaidam Basin; thus, it is hard to evaluate the spatial continuity or connectivity of the crustal LVZs beneath the central and northern plateau and the northwestern Qilian Orogen. Recent magnetotelluric studies [Pape et al., 2012] found that a finger-like extension of the midcrustal conductive anomaly to the north, weakening the Kunlun Mountains 
crust, stops at the east Kunlun-Qaidam border. They suggested that a melt intrusion at the northern edge of the plateau compromises the previous identification of the Kunlun Fault as an important rheological boundary, and the crustal melt penetration probably characterizes the growth of the plateau to the north, as well as accommodates the north-south crustal shortening in the plateau.

Seismic studies based on waveform modeling suggest a 15 to $20 \mathrm{~km}$ Moho offset occurring over a narrow lateral range less than $5 \mathrm{~km}$ near the east Kunlun-Qaidam border [Zhu and Helmberger, 1998]. Receiver function studies found a Moho offset of 10-12 km about $30 \mathrm{~km}$ north of the east Kunlun-Qaidam border [Vergne et al., 2002], and a $15 \mathrm{~km}$ sharp crustal thickness change around $98^{\circ} \mathrm{E}$ [Shi et al., 2009]. Active source seismic profiles also showed a Moho step with a $9 \mathrm{~km}$ offset around the surface location of the east KunlunQaidam border [Li et al., 2004]. Wide-angle seismic data analysis from Karplus et al. [2011] revealed a $20 \mathrm{~km}$ jump in crustal thickness about $45 \mathrm{~km}$ north of the east Kunlun-Qaidam boundary, and the Moho depth changes from $70 \mathrm{~km}$ beneath the Songpan-Ganze Terrane and east Kunlun Mountains to $50 \mathrm{~km}$ beneath the Qaidam Basin. They suggested that a mid-to-lower crustal flow channel exists within the $70 \mathrm{~km}$ thick Songpan-Ganze crust, and the Songpan-Ganze Terrane and east Kunlun Mountains lower crust may underthrust or flow northward beneath the stronger Qaidam Basin crust. Based on the wide-angle reflection data, Jiang et al. [2006] also detected variations of crustal thickness, with a $55 \mathrm{~km}$ thick crust beneath the Qaidam Basin and 65-72 km beneath the Qilian and Kunlun Mountains, an inverse correlation with basement topography. However, to the east of the Qaidam Basin (east of $100^{\circ} \mathrm{E}$ ), the Darlag-Lanzhou-Jingbian seismic profile [Liu et al., 2006] and the Moba-Guide profile [Zhang et al., 2011c] found a gradual transition in Moho depth near the eastern Kunlun Fault around $101^{\circ} \mathrm{E}$. The studies west of $98-100^{\circ} \mathrm{E}$ all show an abrupt decrease in crustal thickness from the east Kunlun Mountains to the Qaidam Basin, but east of $100^{\circ} \mathrm{E}$, a continuous Moho with no abrupt Moho step is preferred through the eastern Kunlun Fault. We note that this lateral variation occurs just around the bend of the eastern Kunlun Fault/Ayimaqin-Kunlun-Mutztagh Suture. Meyer et al. [1998], Jolivet et al. [2003], and Fu and Awata [2007] suggested that the Kunlun Fault may have experienced several phases of initiation and reactivation, so different fault sections may exhibit different responses. The sharp crustal thickness change west of $98-100^{\circ} \mathrm{E}$ implies that the weak and thick Tibetan Plateau crusts are blocked by a strong and thin Qaidam Basin crust. East of $98-100^{\circ} \mathrm{E}$, the bifurcation of the Kunlun Fault system into two branches can be viewed as a broad shear zone that accommodates the plateaus' northward growth. Therefore, a gradual transition in crustal thickness is observed, and the broad shear zone may also accommodate the plateau eastward extrusion.

Low heat flow values ( 44 and $45 \mathrm{mWm}^{-2}$ ) are observed beneath the Qiangtang and Songpan-Ganze Terranes, while the Qaidam Basin has an intermediate value of $54 \mathrm{mWm}^{-2}$, and the Qilian Orogen has a mean value of $66 \mathrm{mWm}^{-2}$ [Wang, 2001]. Wang [2001] proposed that a thick crust can decrease the total strength of the lithosphere due to the significant difference in rheological properties between crustal and mantle lithologies. Crustal thickening and tectonic reactivation of the Qilian Orogen in Cenozoic could cause its relative high heat flow values. Its weak lithosphere with a weak lower crust as well as active seismicity are the prominent characteristics of the Qilian Orogen. In the northern Tibetan Plateau, most Cenozoic magmatic rocks originated from low-degree melting or enriched mantle sources. Crust-derived magmas are scarce. However, a recent petrological study by Wang et al. [2012] reported the finding of crust-derived magmatic rocks, tourmaline-bearing mica, and biotite rhyolites in the Bukadaban-Malanshan area, southern Kunlun Mountains. They suggested that the Bukadaban-Malanshan rhyolites resulted from the partial melting of metasedimentary rocks at $\sim 0.5-1.2 \mathrm{GPa}$ and $740-863^{\circ} \mathrm{C}$, corresponding to depths of $\sim 16-40 \mathrm{~km}$ and a rather long-lived crustal melting history from the mid-Miocene to recent beneath the northern Tibetan Plateau. Therefore, they argued that the felsic magmas which originated from partial melting of the mid-to-lower crust at depths of $16-40 \mathrm{~km}$ are consistent with the observations of weak layers with lower seismic velocity and higher-conductivity zones in the mid-to-lower crust, and the crustal flow could be responsible for the formation of crustal inflation and surface uplift in the northern Tibetan Plateau.

On the basis of Klemperer's flow pattern model [Klemperer, 2006], combining our seismic observations with previous geophysical and geological studies [Karplus et al., 2011; Pape et al., 2012; Wang et al., 2012], we propose that the northern boundary of the mid-to-lower crustal flow regime in the northern Tibetan Plateau is the north Kunlun thrust fault, which marks an abrupt change from a thick crust into a seismically faster and stronger thin crust as shown in Figure 10. The local LVZ beneath the northwestern Qilian Orogen is mainly caused by the crustal thickening of the northwestern Qilian Orogen crust, and the LVZ may be the intracrustal 
(a)

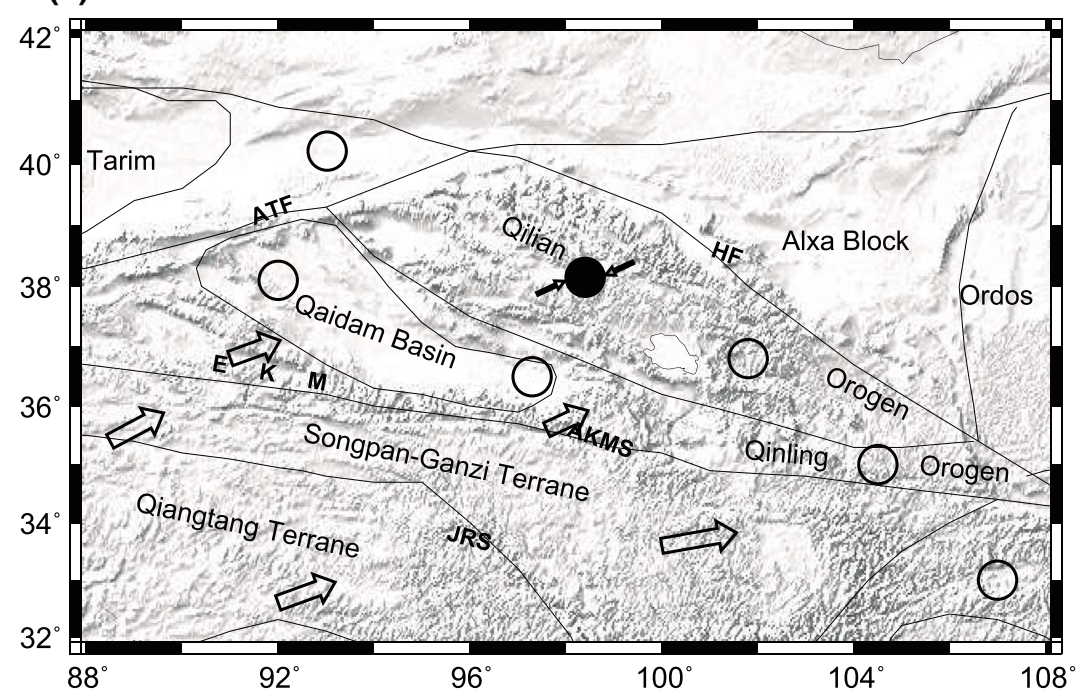

(b)

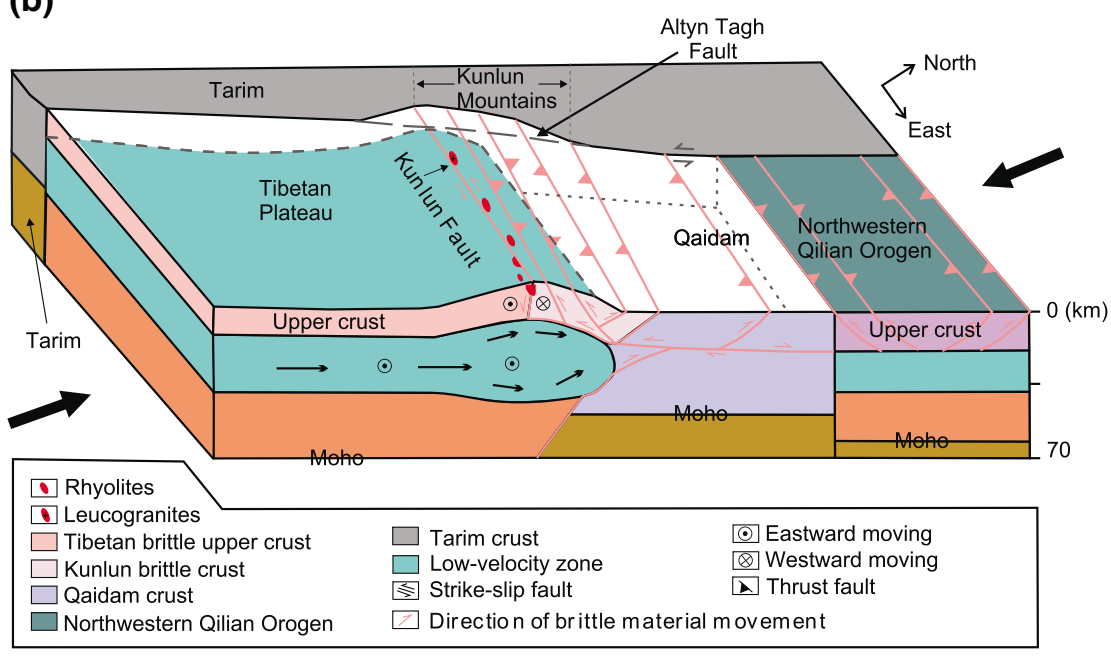

Figure 10. (a) Suggested movements of mid-to-lower crustal channel flow in the northeastern Tibetan Plateau (open arrows) are associated with crustal LVZ and regions of no crustal LVZ (open circles); localized LVZ beneath northwestern Qilian is caused by crustal thickening in response to the shortening between the North China Craton and Tibetan Plateau. (b) A schematic model of the crustal LVZ associated with crustal thickening and surface uplift in the northeastern Tibetan Plateau.

response to accommodate the shortening between the North China Craton and the Tibetan Plateau. The crustal thickening and ongoing NE-SW shortening of the northwestern Qilian Orogen may generate heat that causes partial melting/fluids in the crust as indicated by the low shear velocities, a relative high heat flow value and low magnetotelluric resistivity.

\section{Conclusions}

In this paper, we present observations of Rayleigh wave dispersion derived from continuous seismic data between 2007 and 2010 recorded at 208 stations from the Chinese Provincial Digital Seismic Networks and the temporary ASCENT and NETS experiments. The study region was divided into a $0.4^{\circ} \times 0.4^{\circ}$ grid to invert for group and phase velocity distributions between $8 \mathrm{~s}$ and $50 \mathrm{~s}$. Then a 3-D $V_{s v}$ model is derived from these maps. The 3-D $V_{s v}$ model shows that the Qiangtang and Songpan-Ganze Terranes have a very thick crust with 
a prominent LVZ in the middle crust, and the northwestern Qilian orogeny, where receiver functions reveal a deeper Moho depth than the surrounding areas, also features a relatively weak LVZ in the middle crust. The midcrustal LVZ beneath the Qiangtang and Songpan-Ganze Terranes terminates in the vicinity of the north Kunlun thrust fault, an observation that provides new quantitative constraints about the mode of deformation across the Tibetan Plateau. The local LVZ beneath the northwestern Qilian Orogen may be an intracrustal response associated with the shortening between the North China Craton and the Tibetan Plateau.

\section{Acknowledgments}

We thank two anonymous reviewers, the Associate Editor as well as Editor Robert Nowack, for their constructive critical reviews to improve this manuscript. We thank the China Earthquake Networks center for providing the data. The authors would like to express our appreciation for the PIs and team members of the NETS and ASCENT experiments for collecting those very valuable data in the northeastern Tibetan Plateau. We are grateful to Fenglin Niu of Rice University and Y. John Chen of Peking University who offered the receiver functions results, and Dicheng Zhu of China Uinversity of Geosciences in Beijing for providing geologic and petrological documents. We are thankful to Dan Zheng and Jing Tan for editing some figures. This work was supported by National Science Foundation of China under grant 41174050 and 40804007 , the U.S. National Science Foundation under grant 0738779, the Program for New Century Excellent Talents in University (NCET), and the Fundamental Research Funds for the Central Universities.

\section{References}

Bao, X., X. Song, M. Xu, L. Wang, X. Sun, N. Mi, D. Yu, and H. Li (2013), Crust and upper mantle structure of the North China Craton and the NE Tibetan Plateau and its tectonic implications, Earth Planet. Sci. Lett., 369, 129-137, doi:10.1016/j.epsl.2013.03.015i.

Barazangi, M., and J. Ni (1982), Velocities and propagation characteristics of Pn and Sn beneath the Himalayan arc and Tibetan Plateau: Possible evidence for under-thrusting of Indian continental lithosphere beneath Tibet, Geology, 10, 179-185.

Beaumont, C., R. A. Jamieson, M. H. Nguyen, and B. Lee (2001), Himalayan tectonics explained by extrusion of a low-viscosity crustal channel coupled to focused surface denudation, Nature, 414, 738-742.

Bilham, R., K. Larson, and J. Freymueller (1997), GPS measurements of present- day convergence across the Nepal Himalayas, Nature, 386, 61-64.

Burchifel, B., P. Molnar, Z. Zhao, K. Liang, S. Wang, M. Huang, and J. Sutter (1989), Geology of Ulugh Muztagh area, northern Tibet, Earth Planet. Sci. Lett., 94, 57-70.

Chen, W. P., and T. L. Tseng (2007), Small 660-km seismic discontinuity beneath Tibet implies restingground for detached lithosphere, J. Geophys. Res., 112, B05309, doi:10.1029/2006JB004607.

Clark, M. K., and L. H. Royden (2000), Topographic ooze: Building the eastern margin of Tibet by lower crustal flow, Geology, 28, 703-706.

Constable, S. C., R. L. Parker, and C. G. Constable (1987), Occam's inversion: A practical algorithm for generating smooth models from electromagnetic sounding data, Geophysics, 52, 289-300.

Dewey, J. F., and C. A. Burke (1973), Tibetan, Variscan, and Precambrian basement reactivation: Products of continental collision, J. Geol., 81(6), 683-692, doi:10.1086/627920.

deGroot-Hedlin, C., and S. Constable (1990), Occam's inversion to generate smooth, two-dimensional models from magnetotelluric data, Geophysics, 55, 1613-1624.

Dziewonski, A., S. Bloch, and M. Landisman (1969), A technique for the analysis of transient seismic signals, Bull. Seism. Soc. Am., 59, $427-444$.

England, P., and G. Houseman (1986), Finite strain calculations of continental deformation: 2. Comparison with the India-Asia collision zone, J. Geophys. Res., 91(3), 3664-3676.

England, P., and G. Houseman (1989), Extension during continental convergence with application to the Tibet Plateau, J. Geophys. Res., 94, $17,561-17,579$.

England, P., and P. Molnar (1997), Active deformation of Asia: From kinematics to dynamics, Science, 278, 647-650.

Fu, B. H., and Y. Awata (2007), Displacement and timing of left-lateral faulting in the Kunlun Fault Zone, northern Tibet, inferred from geologic and geomorphic features, J. Asian Earth Sci., 29, 253-265.

Gu, S. S., and H. S. Di (1989), Mechanism of formation of the Qaidam basin and its control on petroleum, in Chinese Sedimentary Basins, Sediment. Basins World, vol. 1, edited by X. Zhu, pp. 45-51, Elsevier, New York.

Herrmann, R. B., and C. J. Ammon (2004), Surface waves, receiver functions and crustal structure, in Computer Programs in Seismology, Version 3.30, Saint Louis University. [Available at http://www.eas.slu.edu/People/RBHerrmann/CPS330.html.]

Herrmann, R. B. (1973), Some aspects of band-pass filtering of surface waves, Bull. Seismol. Soc. Am., 63, 663-671.

Huang, Z., W. Su, Y. Peng, Y. Zheng, and H. Li (2003), Rayleigh wave tomography of China and adjacent regions, J. Geophys. Res. 108(B2), 2073, doi:10.1029/2001JB001696.

Jiang, M., A. Galv, A. Hirn, B. de Voogd, M. Laigle, H. Su, J. Diaz, J. Lepine, and Y. Wang (2006), Crustal thickening and variations in architecture from the Qaidam Basin to the Qang Tang (northcentral Tibetan Plateau) from wide-angle reflection seismology, Tectonophysics, 412, 121-140, doi:10.1016/j.tecto.2005.09.011.

Jolivet, M., M. Brunel, D. Seward, Z. Xu, J. Yang, J. Malavieille, F. Roger, A. Lereloup, N. Arnaud, and C. Wu (2003), Neogene extension and volcanism in the Kunlun Fault Zone, northern Tibet: New constraints on the age of the Kunlun Fault, Tectonics 22(5), 1052, doi:10.1029/2002TC001428.

Karplus, M. S., W. Zhao, S. L. Klemperer, Z. Wu, J. Mechie, D. Shi, L. D. Brown, and C. Chen (2011), Injection of Tibetan crust beneath the south Qaidam Basin: Evidence from INDEPTH IV wide-angle seismic data, J. Geophys. Res., 116, B07301, doi:10.1029/2010JB007911.

Klemperer, S. L. (2006), Crustal flow in Tibet: Geophysical evidence for the physical state of Tibetan lithosphere, and inferred patterns of active flow, 39-70, Geol. Soc. Spec. Publ., 268(1), London, doi:10.1144/GSL.SP.2006.268.01.03.

Kumar, P., X. Yuan, R. Kind, and J. Ni (2006), Imaging the colliding Indian and Asian lithospheric plates beneath Tibet, J. Geophys. Res., 111, B06308, doi:10.1029/2005JB003930.

Li, H., W. Su, C. Wang, and Z. Huang (2009), Ambient noise Rayleigh wave tomography in western Sichuan and eastern Tibet, Earth Planet. Sci. Lett., 282, 201-211.

Li, H., F. Bernardi, and A. Michelini (2010), Surface wave dispersion measurements from ambient seismic noise analysis in Italy, Geophys. J. Int., $180,1242-1252$.

Li, H., S. Li, X. D. Song, M. Gong, X. Li, and J. Jia (2012), Crustal and uppermost mantle velocity structure beneath China from seismic ambient noise tomography, Geophys. J. Int., 188, 131-143.

Li, Q., S. Peng, R. Gao, Y. Guan, and J. Fan (2004), Deep tectonic background of the $8.1 \mathrm{Ms}$ earthquake in the East Kunlun [in Chinese with English abstract], Acta Geosci. Sinica, 25, 11-16.

Litvinovsky, B. A., I. M. Steele, and S. M. Wickham (2000), Silicic magma formation in overthickened crust: Melting of charnockite and leucogranite at 15, 20 and $25 \mathrm{kbar}$, J. Petrol., 41(5), 717-737.

Liu, M., W. Mooney, S. Li, N. Okaya, and S. Detweiler (2006), Crustal structure of the northeastern margin of the Tibetan plateau from the SongpanGanzi terrane to the Ordos Basin, Tectonophysics, 420, 253-266, doi:10.1016/j.tecto.2006.01.025.

Meyer, B., P. Tapponnier, L. Bourjot, F. Metivier, Y. Gademer, G. Peltzer, G. Shunmin, and C. Zhitai (1998), Crustal thickening in GansuQinghai, lithospheric mantle subduction, and oblique, strike-slip controlled growth of the Tibet plateau, Geophys. J. Int., 135, 1-47, doi:10.1046/j.1365-246X.1998.00567.x. 
Molnar, P., and P. Tapponnier (1975), Cenozoic tectonics of Asia: Effects of a continental collision, Science, 189, 419-426.

Owens, T. J., and G. Zandt (1997), Implications of crustal property variations for models of Tibetan plateau evolution, Nature, 387(627), 37-43. Pan, S., and F. Niu (2011), Large constrasts in crustal structure and composition between the Ordos plateau and the NE Tibetan plateau from receiver function analysis, Earth Planet. Sci. Lett., 303, 291-298.

Pape, F., A. G. Jones, J. Vozar, and W. Wei (2012), Penetration of crustal melt beyond the Kunlun Fault into northern Tibet, Nat. Geosci., 5, 330-335, doi:10.1038/NGEO1449.

Rapine, R., F. Tillman, M. West, J. Ni, and A. Rodgers (2003), Crustal structure of northern and southern Tibet from surface wave dispersion analysis, J. Geophys. Res. 108(B2), 2120, doi:10.1029/2001JB000445.

Rowley, D. B. (1996), Age of initiation of collision between India and Asia: A review of stratigraphic data, Earth Planet. Sci. Lett., 145, 1-13.

Royden, L. (1996), Coupling and decoupling of crust and mantle in convergent orogens: Implications for strain partitioning in the crust, J. Geophys. Res., 101, 17,679-17,705.

Royden, L. H., B. C. Burchfiel, R. W. King, E. Wang, Z. Chen, F. Shen, and Y. Liu (1997), Surface deformation and lower crustal flow in eastern Tibet, Science, 276, 788-790.

Royden, L. H., B. C. Burchfiel, and R. D. van der Hilst (2008), The geological evolution of the Tibetan plateau, Science, 321, $1054-1058$.

Shen, F., L. H. Royden, and B. C. Burchfiel (2001), Large-scale crustal deformation of the Tibetan Plateau, J. Geophys. Res., 106(B4), 6793-6816.

Shi, D., Y. Shen, W. Zhao, and A. Li (2009), Seismic evidence for a Moho offset and south-directed thrust at the easternmost Qaidam-Kunlun boundary in the Northeast Tibetan plateau, Earth Planet. Sci. Lett., 288, 329-334.

Tapponnier, P., G. Peltzer, R. Armijo, A. Le Dain, and P. Cobbold (1982), Propagating extrusion tectonics in Asia: New insights from simple experiments with plasticine, Geology, 10, 611-616.

Tapponnier, P., Z. Xu, F. Roger, B. Meyer, N. Arnaud, G. Wittlinger, and J. Yang (2001), Oblique stepwise rise and growth of the Tibet Plateau, Science, 294(5547), 1671-1677.

Tilmann, F., J. Ni, and INDEPTH III Seismic Team (2003), Seismic imaging of the downwelling Indian lithosphere beneath central Tibet, Science, 300, 1424-1427.

Vergne, J., G. Wittlinger, Q. Hui, P. Tapponnier, G. Poupinet, M. Jiang, G. Herquel, and A. Paul (2002), Seismic evidence for stepwise thickening of the crust across the NE Tibetan plateau, Earth Planet. Sci. Lett., 203, 25-53.

Wang, Q., S. L. Chung, X. H. Li, D. Wyman, Z. X. Li, W. D. Sun, H. N. Qiu, Y. S. Liu, and Y. T. Zhu (2012), Crustal melting and flow beneath northern Tibet: Evidence from Mid-Miocene to Quaternary strongly peraluminous rhyolites in the southern Kunlun Range, J. Petrology, 53(12), 2523-2566, doi:10.1093/petrology/egs058.

Wang, Y. (2001), Heat flow pattern and lateral variations of lithosphere strength in China mainland: Constraints on active deformation, Phy Earth Planet. Int., 126, 121-146.

Wittlinger, G., et al. (1996), Seismic tomography of northern Tibet and Kunlun: Evidence for crustal blocks and mantle velocity contrasts, Earth Planet. Sci. Lett., 243, 195-210, doi:10.1016/j.epsl.2005.11.033.

Wittlinger, G., V. Farra, and J. Vergne (2004), Lithospheric and upper mantle stratifications beneath Tibet: New insights from Sp conversions, Geophys. Res. Lett., 31, L19615, doi:10.1029/2004GL020955.

Yang, Y., et al. (2010), Rayleigh wave phase velocity maps of Tibet and the surrounding regions from ambient seismic noise tomography, Geochem. Geophys. Geosyst., 11, Q08010, doi:10.1029/2010GC003119.

Yang, Y., M. H. Ritzwoller, Y. Zheng, W. Shen, A. Levshin, and Z. Xie (2012), A synoptic view of the distribution and connectivity of the mid-crustal low velocity zone beneath Tibet, J. Geophys. Res., 117, B04303, doi:10.1029/2011JB008810.

Yin, A., and M. Harrison (2000), Geological evolution of the Himalayan- Tibetan orogen, Annu. Rev. Earth Planet. Sci., 28, 211-280.

Yue, H., et al. (2012), Lithospheric and upper mantle structure of the northeastern Tibetan Plateau, J. Geophys. Res., 117, B04303, doi:10.1029/2011JB008545.

Zhang, Q., E. Sandvol, J. Ni, Y. Yang, and Y. Chen (2011a), Rayleigh wave tomography of the northeastern margin of the Tibetan Plateau, Earth Planet. Sci. Lett., 304, 103-112, doi:10.1016/j.epsl.2011.01.021.

Zhang, Z., L. Yang, J. Teng, and J. Badal (2011b), An overview of the earth crust under China, Earth Sci. Rev., 104, $143-166$.

Zhang, Z., S. Klemperer, Z. Bai, Y. Chen, and J. Teng (2011c), Crustal structure of the Paleozoic Kunlun orogeny from an activesource seismic profile between Moba and Guide in east Tibet, China, Gondwana Res., 19, 994-1007, doi:10.1016/j.gr.2010.09.008.

Zhao, J., W. D. Mooney, X. Zhang, Z. Li, Z. Jin, and N. Okaya (2006), Crustal structure across the Altyn Tagh Range at the northern margin of the Tibetan plateau and tectonic implications, Earth Planet. Sci. Lett., 241, 804-814.

Zhu, L., and D. V. Helmberger (1998), Moho offset across the northern margin of the Tibetan Plateau, Science, 281, 1170-1172. 